\title{
POSSIBLE SIGHTING OF LESSER GOLDFINCH
}

JOHN DOUGLAS, Box 602, Maple, Creek, SK SON 1NO

I published a note in the Maple Creek News on 8 September 1998, headed 'Unusual sighting in Maple Creek. Wayne C. Harris, regional biologist, sent a copy to Dr. Stuart Houston and he has encouraged me to submit my observation to Blue Jay. The following is a slightly augmented version of what appeared in the weekly newspaper here.

While I was driving home one afternoon in mid-August 1997, I spotted a small flock of goldfinches, feeding on the seeds of wild sunflowers at the edge of the road. Then I noticed one of them looked as if he had been dipped in green paint, and a couple more had a greenish tinge. I know that female and young American Goldfinches can have a faint greenish tinge, but this one bird was really green!

When we got home, my wife and I looked up the green bird in our National Geographic Society Field Guide to the Birds of North America. The only bird it resembled was a Lesser Goldfinch (Carduelis psaltria). However, this bird's normal range is quite a bit further south in the States. I suppose this a possible example of wandering migrants than can occur in the spring and fall. The 7th edition of the A.O.U. Check-List of North American Birds (1998) states that the Lesser Goldfinch is "Casual or accidental in British Columbia, Montana, southwestern South Dakota. ..."

Another day when I was driving spotted a Northern Harrier, commonly known as a Marsh Hawk, perched on a fence. As I passed, it flew and kept pace with my car as I slowly drove along. It continued to fly 30 to 40 feet to the side of me for two miles over an area of grass and weeds. Then it hovered, and dove. I stopped the car and saw the hawk had made a kill. It was apparently used to vehicles stirring up small game on the prairie. I thought this was an example of smart hunting.

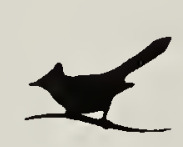

A Bishop in 1555, insisted that northern species roosted in reed beds over winter. His theory was the birds would sit in the reed beds gradually sinking into the mud until they finally just fell asleep. 